\title{
Effect of Precursor's Composition and Thickness on Foaming Behavior of Al-Tiintermetallics in Volume Combustion and Self-propagating High-temperature Synthesis Modes
}

\author{
Makoto Kobashi ${ }^{1}$, Naoyuki Kanetake ${ }^{1} \&$ Soshiro Murata $^{2}$ \\ ${ }^{1}$ Department of Materials Science and Engineering, Nagoya University, Nagoya, Japan \\ ${ }^{2}$ School of Engineering, Nagoya University, Nagoya, Japan \\ Correspondence: Makoto Kobashi, Department of Materials Science and Engineering, Nagoya University, 1 \\ Fro-cho, Chikusa-ku, Nagoya 4648603, Japan. Tel: 81-52-789-3356. E-mail: kobashi@numse.nagoya-u.ac.jp
}

\author{
Received: June 23, 2012 Accepted: July 13, 2012 Online Published: August 8, 2012 \\ doi:10.5539/jmsr.v1n4p1 URL: http://dx.doi.org/10.5539/jmsr.v1n4p1
}

The research is financed by Industrial Technology Research Grant Program in 2008 from NewEnergy and Industrial Technology Development Organization (NEDO) of Japan

\begin{abstract}
Sheet type precursors made of aluminum, titanium, and boron carbide $\left(\mathrm{B}_{4} \mathrm{C}\right)$ powders were prepared by rolling, and porous Al-Ti intermetallics were fabricated by a combustion reaction in volume combustion synthesis (VCS) and self-propagating high-temperature synthesis (SHS) modes. The effects of precursor's composition and thickness on the foaming behavior were investigated.The microstructure of the precursor was not affected by rolling. In the VCS mode, the thin precursor $(1 \mathrm{~mm})$ with a high $\mathrm{Al} / \mathrm{Ti}$ blending ratio $(\mathrm{Al} / \mathrm{Ti}=7.0) \mathrm{did}$ not expand sufficiently. The microstructure of the specimen after the reaction revealed that the reaction between titanium and aluminum was not completed in this specimen. This means that the maximum temperature during the reaction decreased by decreasing the thickness and increasing the Al/Ti blending ratio. The self-propagating high-temperature synthesis mode combustion reaction propagated through the whole specimen when the $\mathrm{Al} / \mathrm{Ti}$ ratio was 4.0 and the thickness of the precursor was $4 \mathrm{~mm}$ or more. However, by reducing the thickness of the precursors to $2 \mathrm{~mm}$ or less, the reaction front did not propagate through the whole specimen. The self-propagation also became difficult by increasing the Al/Ti ratio to 7.0. Theseresults imply that the SHS mode reaction was more susceptible to precursor's composition and thickness than the VCS mode reaction. Fine pores with diameters below $1 \mathrm{~mm}$ are dispersed in the specimen by the SHS mode reaction.
\end{abstract}

Keywords: foam material, porous material, powder metallurgy, combustion synthesis, composite material

\section{Introduction}

Porous metals exhibit various unique physical and mechanical properties, such as low bulk density and high strain energy absorbing capability (Baumeister et al., 1997; Banhart et al., 1998, 2001). Porous aluminum is one of the most investigated materials among the wide variety of porous metals (Chino et al., 2002; Duarte et al., 2000; Asavavisithchai et al., 2006; Matijasevic et al., 2006; Gergely et al., 2004) because of the availability of effective blowing agents like titanium hydride $\left(\mathrm{TiH}_{2}\right)$, zirconium hydride $\left(\mathrm{ZrH}_{2}\right)$, and carcium carbonate $\left(\mathrm{CaCO}_{3}\right)$. The blowing agent decomposes and releases a gaseous phase at around the melting point of aluminum or its alloys (Kennedy et al., 2003, 2002; Matijasevic-Lux et al., 2006; Cambronero et al., 2009; Zeppelin et al., 2003). If metals can be substituted by intermetallics or their composites, these porous materials can be used in severe environments, e.g., thermal barrier coatings at high temperatures and heavy load-bearing components (Hodge et al., 2001; Darolia et al., 2000; Zhao et al., 2005). However, the melting points of intermetallics are generally higher than those of light metals, and this makes the process of introducing pores into the intermetallics difficult. To overcome this problem, the authors have developed a novel fabrication process for porous materials using a combustion reaction (a reactive precursor process) (Kanetake et al., 2006; Kobashi et al., 2010a). Combustion synthesis is one attractive processing route for producing intermetallics and their composites because high-melting-point materials can be produced with little energy and without special equipment (Lee et al., 2000; Dumez et al., 1998). Pore formation is a well-known intrinsic feature of the combustion reaction (Varma et 
al., 1992; Morsi et al., 2012). Gas phases originally absorbed in or adsorbed at the reactant powders are the main sources for the pore formation (Kobashi et al., 2010b). In this research aluminum and titanium powders were used, and the basic reaction used in this processis shown below.

$$
\alpha A l+\mathrm{Ti} \rightarrow \mathrm{Al}_{3} \mathrm{Ti}+(\alpha-3) \mathrm{Al}+146 \mathrm{~kJ} / \mathrm{mole} \mathrm{Ti}
$$

In order to increase the porosity, boron carbide $\left(\mathrm{B}_{4} \mathrm{C}\right)$ powder is blended into the compacted powder precursor. The $\mathrm{B}_{4} \mathrm{C}$ powder reacts with titanium and generates a large amount of reaction heat as shown in the following equation.

$$
\mathrm{Ti}+1 / 3 \mathrm{~B}_{4} \mathrm{C} \rightarrow 2 / 3 \mathrm{TiB}_{2}+1 / 3 \mathrm{TiC}+254 \mathrm{~kJ} / \mathrm{mole} \mathrm{Ti}
$$

This reaction heat assists in $\mathrm{Al}_{3} \mathrm{Ti}$ formation and is effectiveto enhance the foaming behavior (Inoguchi, et al., $2009 \mathrm{~b}$ ). Therefore, $\mathrm{B}_{4} \mathrm{C}$ and an equivalent amount of titanium, which is required for Equation (2), were used as the "exothermic agent". In the previous study, the authors reported thatthe adequit additional amount of the exothermic agent was in between 5 and 10 vol\% (Kobashi et al., 2010a), $\mathrm{Al}_{3} \mathrm{Ti}$ is more foamable than TiAl (Inoguchi et al.,2009a) and the $\mathrm{Al}_{3} \mathrm{Ti} / \mathrm{Al}$ composite foam exhibited high plateau stress (Inoguchi et al., 2009b).

One of the most notable advantages of this process is that a porous material can be manufactured by both volume combustion synthesis (VCS) and self-propagating high-temperature synthesis (SHS) modes. In the SHS mode, only part of the precursor is heated. Once the reaction in the heated zone is initiated and the heat of reaction is released, the neighboring zone is then heated and starts to react. After the reaction propagates through the specimen, a long or large scale product is syntheseized. Therefore, this manufacturing process does not require a large amount of external heat to raise the temperature of the whole speimen. However, the combusiton reaction is a self-heating process and, therefore, quite sensitive to the size of the specimen because heat dissipasion from the surface is severe when the specific surface area becomes large. In this paper, we focus on the foaming behavior of extruded and rolled precursors and report the effects of composition and precursor thickness on the foaming behavior in both the VCS and SHS modes.

\section{Experimental Procedure}

Figure 1 illustrates the brief concept of the reactive precursor process for the synthesis of porous $\mathrm{Al}_{3} \mathrm{Ti} / \mathrm{Al}$ composites in the VCS mode. Aluminum ( $<45 \mu \mathrm{m}, 99.99 \%)$, titanium $(<45 \mu \mathrm{m}, 99.9 \%)$, and $\mathrm{B}_{4} \mathrm{C}$ (avg. $10 \mu \mathrm{m}$, $99 \%$ ) powders were used as starting powders. The aluminum and titanium powders were first blended with pre-fixed molar ratios $\left(\mathrm{Al} / \mathrm{Ti}=4.0\right.$ and 7.0), and the $\mathrm{B}_{4} \mathrm{C}$ powder and an equivalent amount of titanium powder, which is spent in the reaction shown in Equation (2), were additionally blended (exothermic agent). The amount of exothermic agent was defined by the volume fraction of the ceramic particles $\left(\mathrm{TiC}, \mathrm{TiB}_{2}\right)$ in the solid section and was set to 10.0 vol\%. After all the elemental powders were blended, the blended powder was cold compacted by $400 \mathrm{MPa}$ and hot extruded to a $10 \mathrm{~mm}$ diameter rod at $673 \mathrm{~K}$. This rod was then hot rolled at 673 $\mathrm{K}$ into plates with the thickness of 1,2, and $4 \mathrm{~mm}$ as shown in Figure 2. For the VCS mode, the entire precursor $(L=30 \mathrm{~mm})$ was heated by an induction coil as shown in Figure 3 .

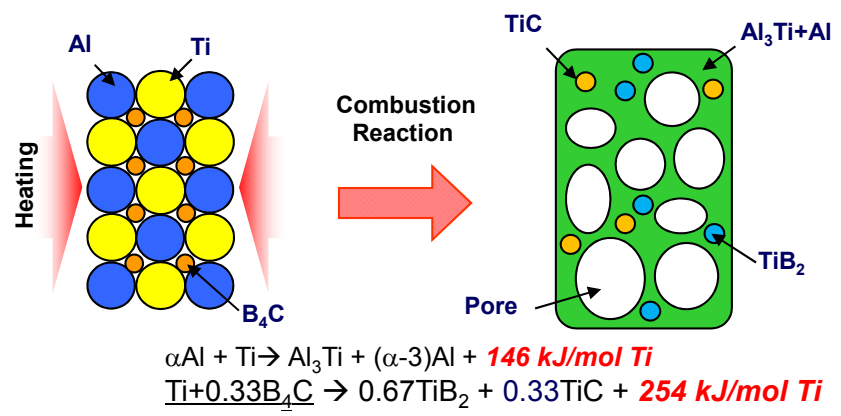

Figure 1. Schematic illustration of combustion foaming process for $\mathrm{Al}_{3} \mathrm{Ti} / \mathrm{Al}$ composite foam 


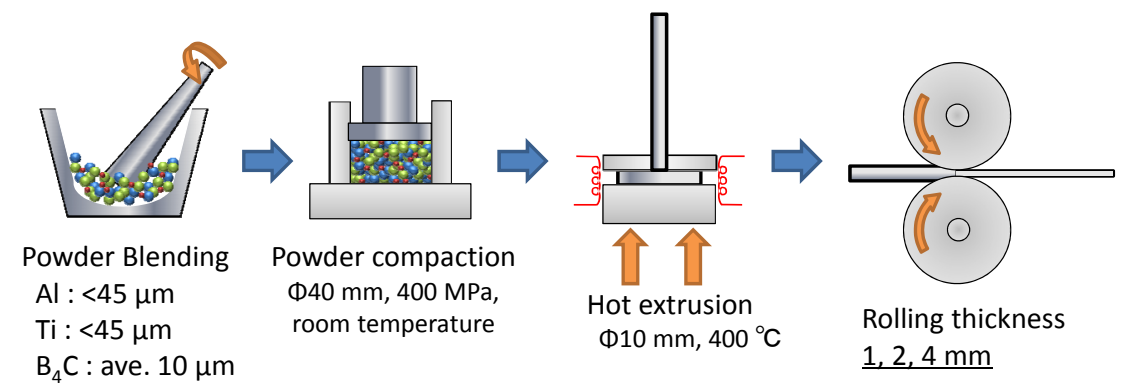

Figure 2. Schematic illustration of the experimental procedure for manufacturing rolled precursors

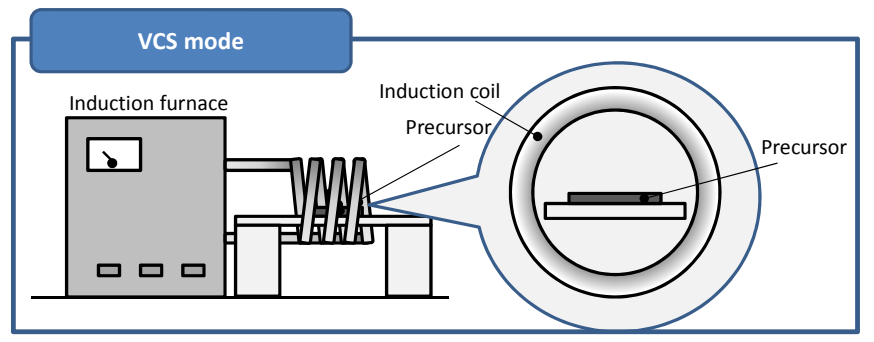

Figure 3. Schematic illustration of the experimental apparatus for VCS mode and (b) SHS mode

Figure 4 shows a schematic illustration and sequantial photographs of the self-propagating synthesis mode of the combustion reaction. Partial heating was applied to the precursor $(L=100 \mathrm{~mm})$ by an induction coil for the SHS mode as shown in Figure 5. The induction power supply was stopped immediately after the ignition of the combustion reaction. The experiment was carried out in air, and the temperature of the specimen during the self-propagating reaction was measured by an infrared pyrometricvideo monitor. The porosity was evaluated by the area fraction of the pores in a cross-section of the specimen by image analyzing software.
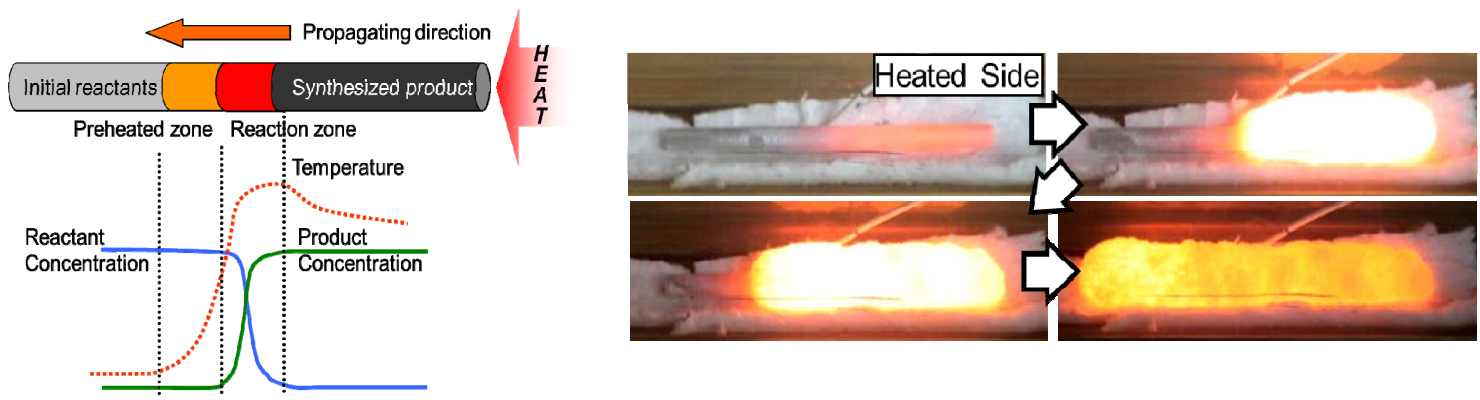

Figure 4. Schematic illustration and sequantial photographs of the self-propagating synthesis mode of the combustion reaction

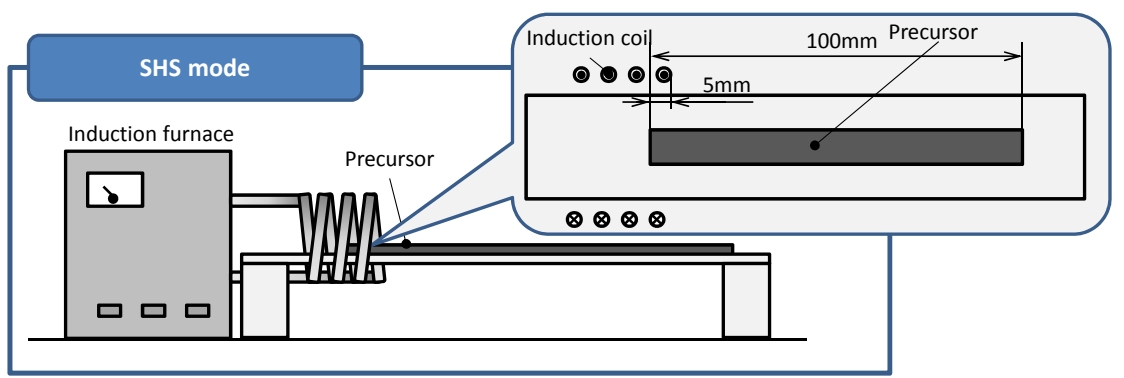

Figure 5. Schematic illustration of the experimental apparatus for VCS mode and (b) SHS mode 


\section{Results and Discussion}

\subsection{Microstructure of Rolled Precursor}

Figure 6 shows photographs of the as-prepared rolled sheet precursors. Although some severe edge cracks were observed when the sheet thickness was reduced to $1 \mathrm{~mm}$, all the Al-Ti- $\mathrm{B}_{4} \mathrm{C}$ precursor could be rolled to the prefixed thickness. Figure 7 shows scanning electron microscopy (SEM) images of the precursors. It is clear that the microstructure of the precursor was not affected significantly by rolling. Equiaxed titanium and $\mathrm{B}_{4} \mathrm{C}$ powders were embedded in the aluminum matrix. By this observation, it was confirmed that the rolling did not give a severe effect on the microstructure of the precursors.

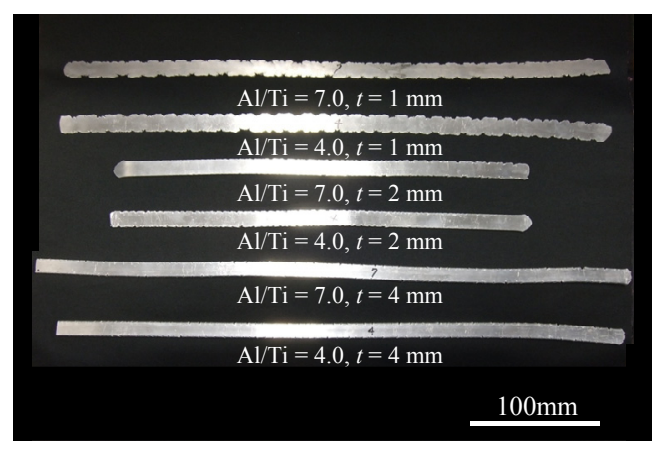

Figure 6. The sheet precursors rolled to various thicknesses

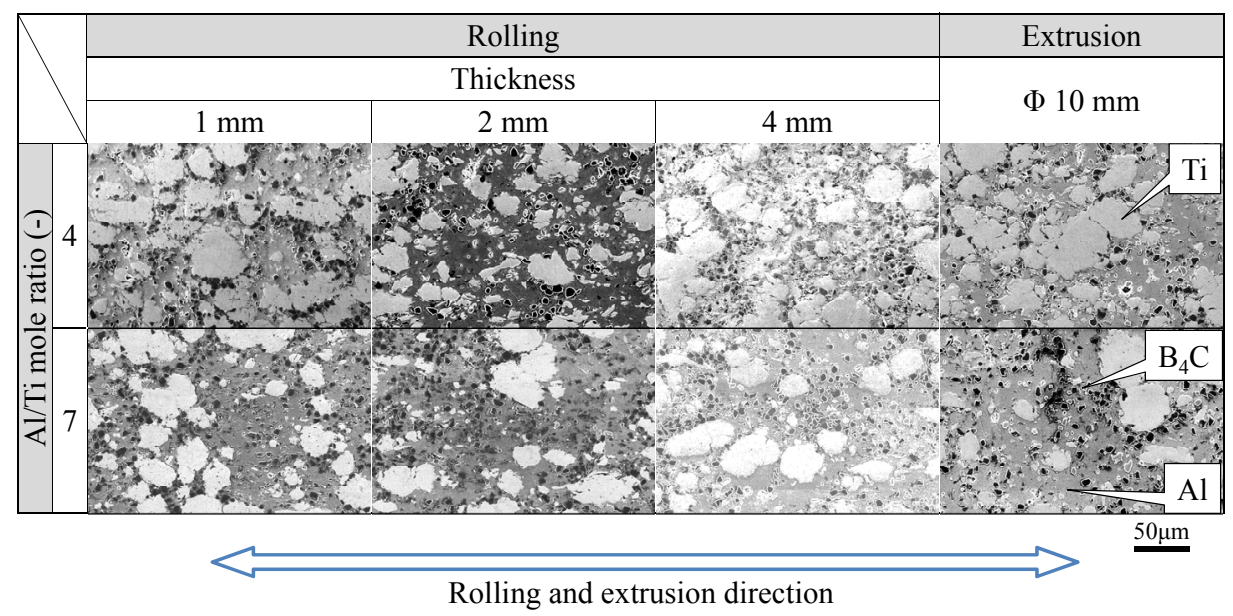

Figure 7. Microstructures of the rolled and as-extruded precursors

\subsection{Foaming Behavior in VCS Mode}

Cross-sections of the specimens fabricated in the VCS mode are shown in Figure 8. Most specimens expanded during the reaction and resulted in exhibiting the porous structure. The porosity of the expanded specimens exceeded 50\%. However, the thinest precursor $(1 \mathrm{~mm})$ with the higher $\mathrm{Al} / \mathrm{Ti}$ ratio $(\mathrm{Al} / \mathrm{Ti}=7.0)$ did not expand sufficiently. The following factors are considered as the main reasons for the low porosity.

1) The excess amount of aluminum absorbed the heat of reaction.

2) The thin thickness (high specific surface area) increases the radiation heat loss during the combustion reaction.

Both factors reduced the combustion temperature (a maximum temperature during the combustion reaction) and resulted in a decrease in the liquid phase formation. In order to confirm wheather the reaction between aluminum and titanium was affected by the $\mathrm{Al} / \mathrm{Ti}$ ratio and the thickness of the precursors, the microstructure of the specimen after the reaction was obserbed by SEM.Figure9 shows the microstructure of the cell wall of each specimen. The microstructure mainly consisted of two phases: a continuous matrix region (darker pahse) and 
some dispersed phases (brighter phase). An energy dispersive X-ray (EDX) analysis was carried out for these phases and the darker and brighter phases turned out be aluminm and $\mathrm{Al}_{3} \mathrm{Ti}$, respectively. As already reported in the previous paper, both $\mathrm{TiB}_{2}$ and $\mathrm{TiC}$ particles were dispersed in aluminum matrix as fine particles of about a few microns in diameter (Kobashi et al., 2009a). In this study, the formation of $\mathrm{Al}_{3} \mathrm{Ti}$ was confirmed in all specimens. The shape of $\mathrm{Al}_{3} \mathrm{Ti}$ was fine granular only when $\mathrm{Al} / \mathrm{Ti}$ ratio was 7.0 and the thickness of the precursor was $1 \mathrm{~mm}$. Relatively larger plate-like $\mathrm{Al}_{3} \mathrm{Ti}$ was formed in other specimens. It was reported that the size and the shape of $\mathrm{Al}-\mathrm{Ti}$ intermetallics is related to the $\mathrm{Al} / \mathrm{Ti}$ blending ratio and the combustion temperature (Kandalova et al., 2002). It was also reported that the fine granular shape was produced when the combustion temperature was low. This indicates that the temperature of the specimen with $7.0 \mathrm{Al} / \mathrm{Ti}$ ratio and $1 \mathrm{~mm}$ thickness in this study did not rise as high as other specimens. Figure 10 shows the microstructure of the specimen's cell wall with (a) Al/Ti $=4.0 ; t=2 \mathrm{~mm}$, and (b) $\mathrm{Al} / \mathrm{Ti}=7.0 ; t=1 \mathrm{~mm}$. The EDX analysis was carried out for these specimens. The reaction products, both the block- and needle-like $\mathrm{Al}_{3} \mathrm{Ti}, \mathrm{TiC}$, and $\mathrm{TiB}_{2}$, are observed in Figure 10 (a), and unreacted titanium and $\mathrm{B}_{4} \mathrm{C}$ are observed in Figure 10 (b). This means that the $\mathrm{B}_{4} \mathrm{C}$ did not play its role as an exothermic agent. When the thickness of the precursor was $1 \mathrm{~mm}$, radiation from the specimen overwhelmed the heat of the combustion reaction. Additionally, the heat of reaction decreases by increasing the Al/Ti ratio. As a result, the temperature of the specimen did not increase high enough to obtain the porous structure. This may be the main reason for the low porosity ( $33 \%$ ) of high $\mathrm{Al} / \mathrm{Ti}$ ratio and thin precursor.

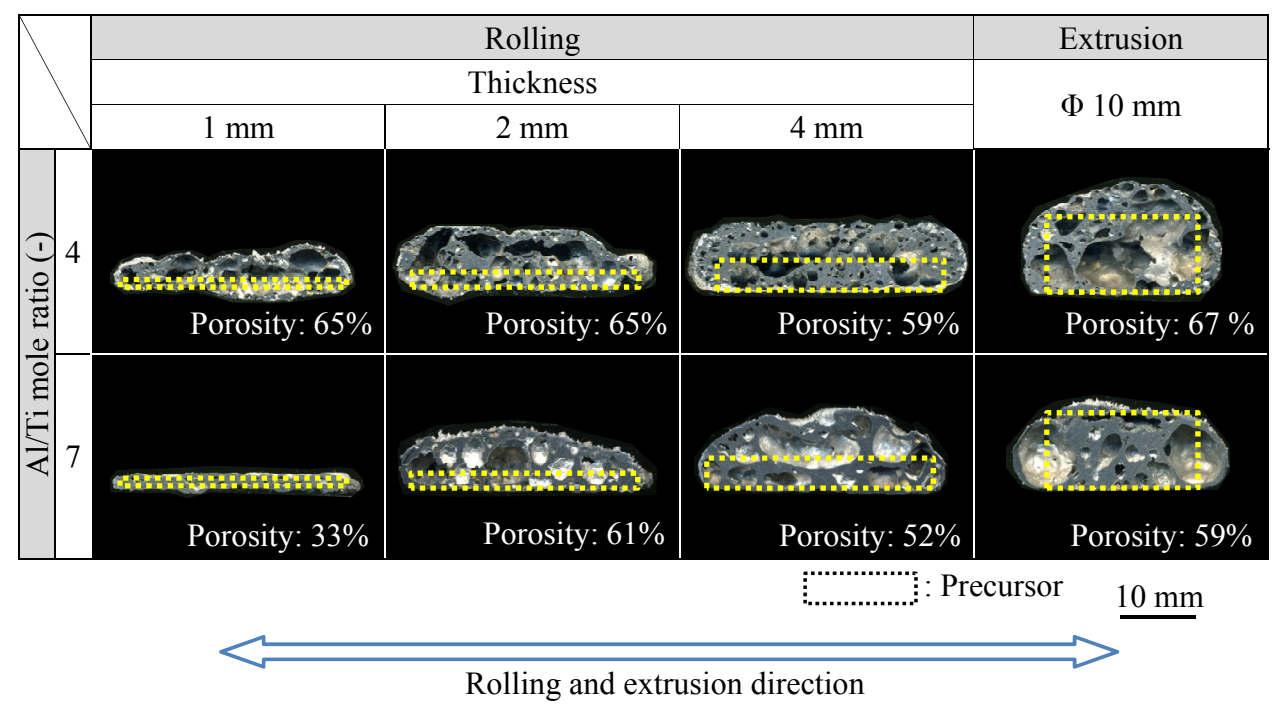

Figure 8. Cross-sections of the porous specimens after the combustion reaction in the VCS mode

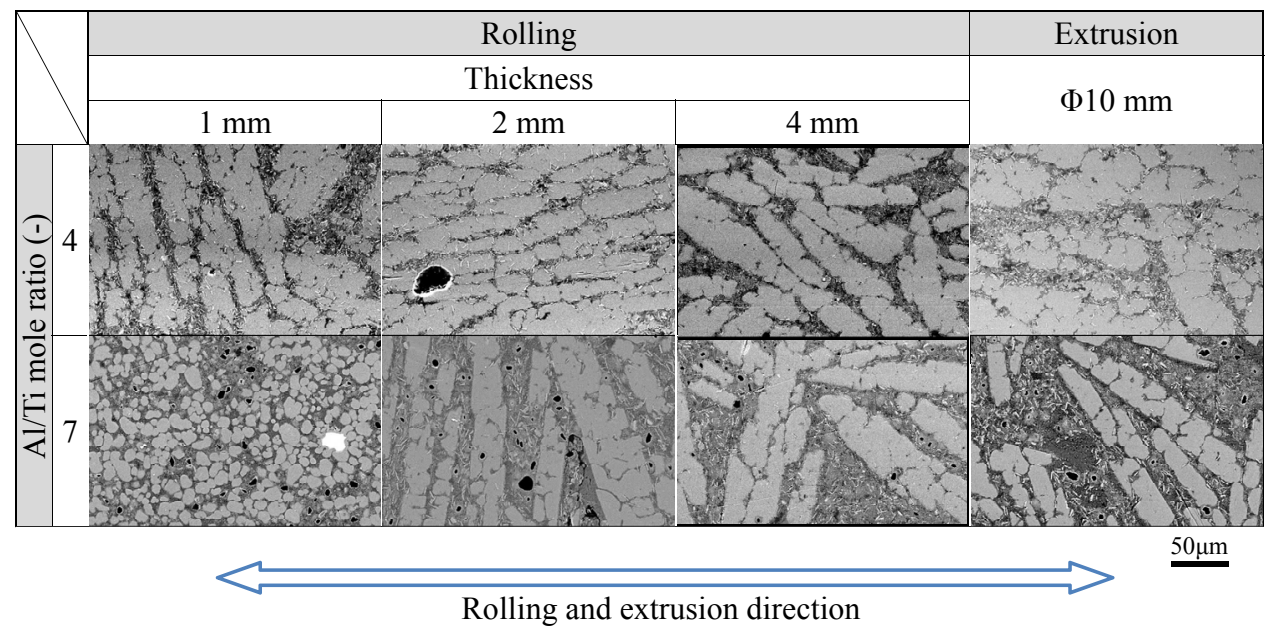

Figure 9. Microstructure of the porous specimens after the combustion reaction in the VCS mode 

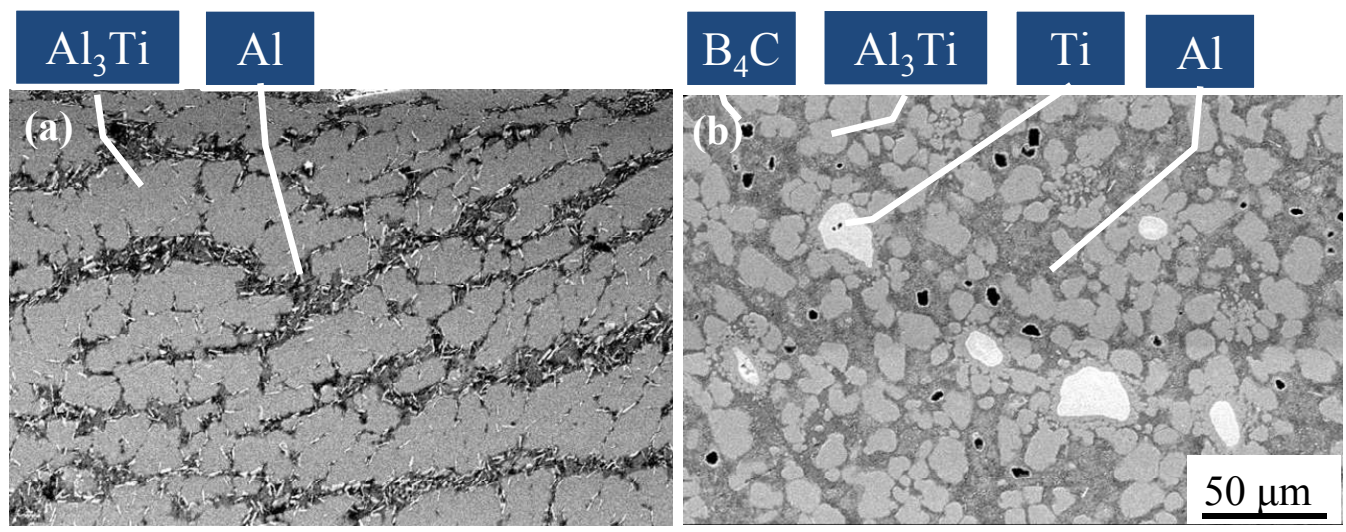

Figure 10. Microstructure of the cell wall: (a) $\mathrm{Al} / \mathrm{Ti}=4.0 ; t=2 \mathrm{~mm}$ and (b) $\mathrm{Al} / \mathrm{Ti}=7.0 ; t=1 \mathrm{~mm}$

\subsection{Foaming Behavior in SHS Mode}

Partial heating of the specimen was carried out to induce the combustion reaction in the SHS mode. Figure 11 shows the temperature profiles of the precursor for a $10 \mathrm{~mm}$ diameter rod and a $t=1 \mathrm{~mm}$ sheet at various points with $20 \mathrm{~mm}$ intervals (\#1-\#5). Clear temperature peaks were identified in Figure 11(a) from points \#1 to \#5. This indicates that the combustion reaction propagated steadily at a relatively constant velocity $(4 \mathrm{~mm} / \mathrm{s})$. However, by reducing the thickness of the precursor down to $1 \mathrm{~mm}$, a clear peak was no longer identified except for the ignition point (\#1), indicating that the combustion reaction took place only at the heated end. A slight increase in the temperature at point $\# 2$ might be caused by conducted heat from point $\# 1$. The cross-sections of these specimens are shown in Figure 12. The cross-sections proved that the pores are observed at the points where the sharp temperature peaks were detected.The average porosity of the specimen (Al/Ti ratio: $4.0,10 \mathrm{~mm}$ rod) was $67 \%$, which was the same level as the VCS-mode specimen. This means that the high porosity can be achieved by the SHS mode on some conditions (low Al/Ti ratio and large thickness of the precursors). Figure 13 shows the specimens of various thicknesses after the partial heating to ignite the reaction. The left-hand side of the specimen was the heated side, and the SHS reaction propagated from left to right. The combustion reaction propagated through the whole specimen when the thickness of the precursor exceeded $4 \mathrm{~mm}$. However, when the thickness of the precursor was reduced to $2 \mathrm{~mm}$ or less, the reaction front did not propagate through the whole specimen. The inverted triangles and an arrow in Figure 13 indicate the point at which the self-propagation was terminated and a distance of the self-propagation, respectively. Figure 14 illustrates the relation between the self-propagation distance and the specific surface area of the precursor. The self-propagation distance decreased by increasing the specific surface area (decreasing the thickness). The radiation heat loss from the precursor became prominent by increasing the specific surface area of the precursor, since the ambient temperature is much lower than the specimen temperature in the combustion reaction process. From the results obtained in this section, the specimen size turned out to be very important to realize the self-propagating foaming behavior. When the specific surface area is higher than a critical value, heat radiation from the precursor during the reaction becomes too severe to maintain theself-propagating reaction. Therefore, some kinds of additional modification, e.g. pre-heating the precursor or increasing the exothermic agent addition, are needed for thin precursors. Finally, Figure 15 shows the crosssections of the specimen with the Al/Ti ratio of 4.0 and the thickness of $4 \mathrm{~mm}$. It is seen that the fine pores with diameters below $1 \mathrm{~mm}$ are dispersed in the specimen except for the heated side. The porosity of the specimen was $31 \%$ (the heated end was eliminated from the evaluation). Such small pores were not observed in the specimens fabricated by the VCS mode. This may be caused by the rapid cooling rate of the specimen. In the SHS mode, heating and cooling occurs in a shorter period of time in comparison with the VCS mode, and, therefore, the growth of the pores tended to be prevented. Although a further investigation is needed for a betterunderstanding of this phenomenon, this result implies that the SHS mode combustion reaction is an attractive process for producing fine pores. 


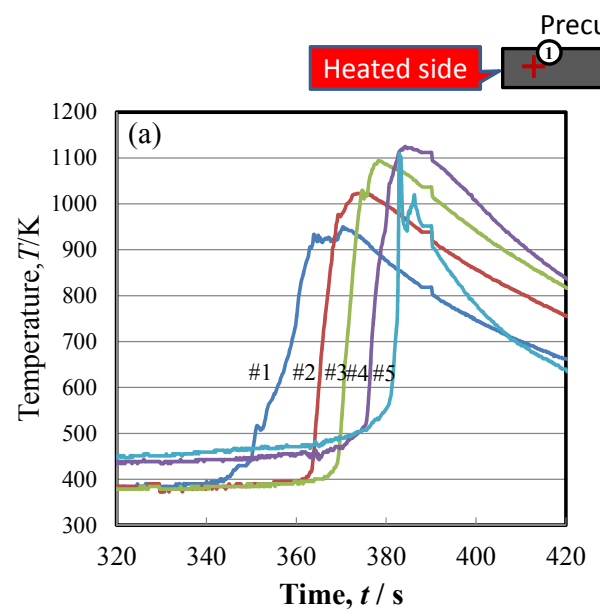
Precursor $12+3$

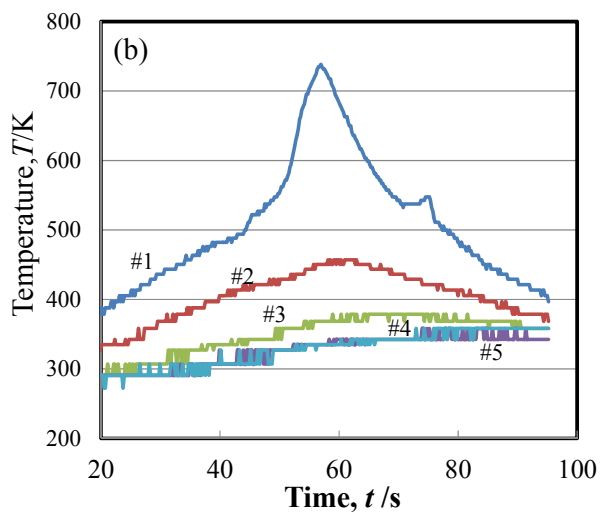

Figure 11. Temperature profiles of the SHS mode specimens: (a) $10 \mathrm{~mm}$ diameter rod and (b) $1 \mathrm{~mm}$ thick sheet

(a)

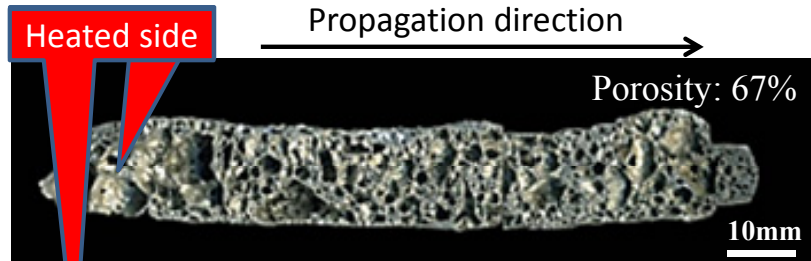

(b)

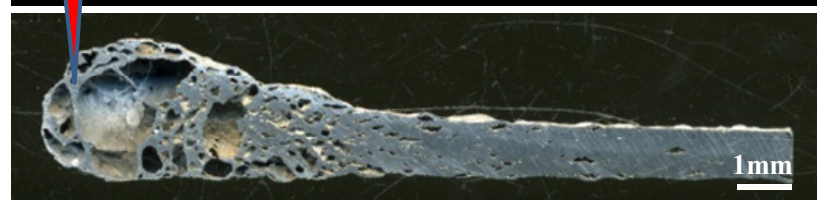

Figure 12. Cross-sections of the SHS mode specimens: (a) $10 \mathrm{~mm}$ diameter rod and (b) $1 \mathrm{~mm}$ thick sheet

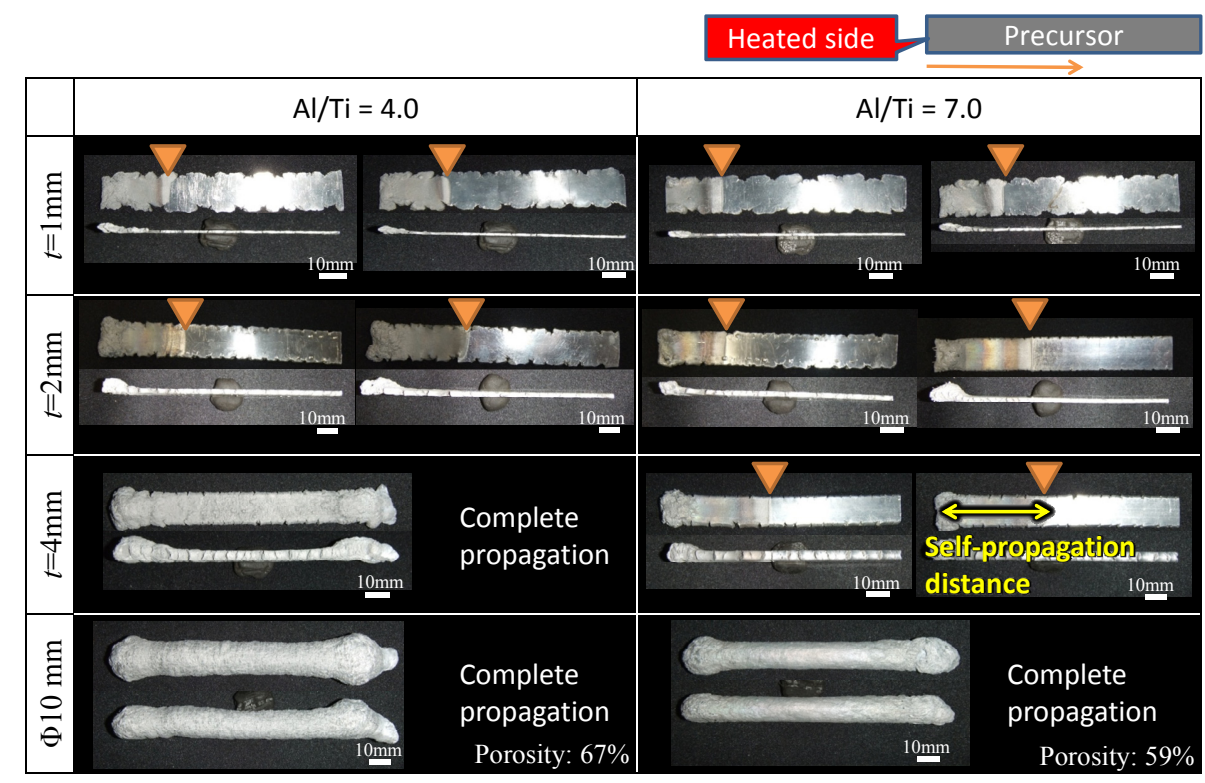

Figure 13. Appearance of $\mathrm{Al}_{3} \mathrm{Ti}$ / Alfoam synthesized in the SHS mode combustion reaction ( $\boldsymbol{\nabla}$ : termination point of self-propagating reaction) 


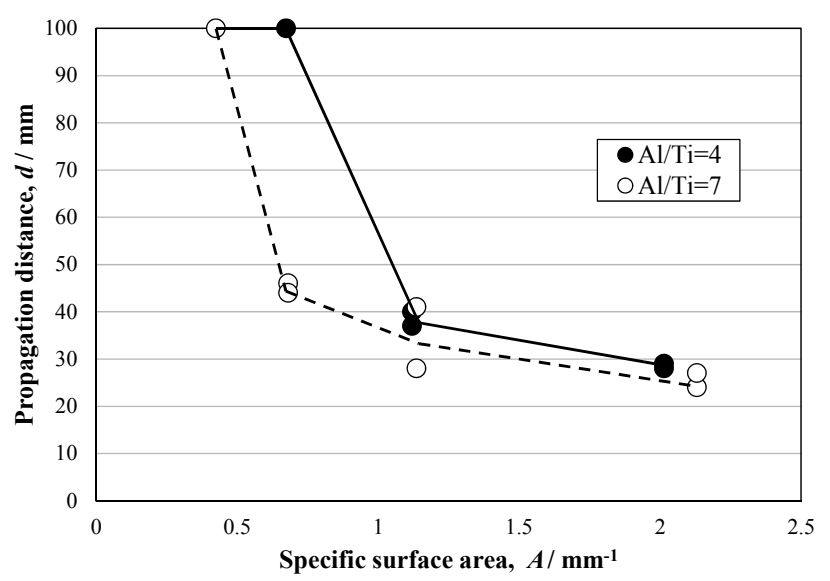

Figure 14. Propagation distance of self-propagating reaction as a function of specific surface area of precursor
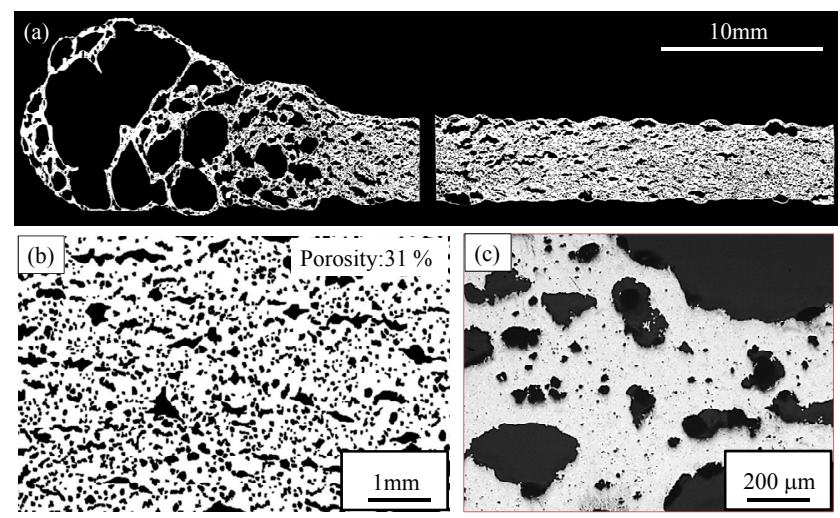

Figure 15. Coss-sectional images of $\mathrm{Al} / \mathrm{Al}_{3} \mathrm{Ti}$ foam synthesized by SHS reaction;(a) Binarymacroscopic image,

(b) Binary microscopic image and (c) SEM microscopic image.( $\mathrm{Al} / \mathrm{Ti}=4.0, t=4 \mathrm{~mm})$

\section{Conclusions}

Sheet type precursors made of $\mathrm{Al}, \mathrm{Ti}$, and $\mathrm{B}_{4} \mathrm{C}$ powders were prepared, and the effect of precursor's composition and thickness on foaming behavior of $\mathrm{Al}_{3} \mathrm{Ti}$ intermetallics in volume combustion and self-propagating high-temperature synthesis modes were investigated.

1) The microstructure of the precursor was not affected by rolling. Equiaxed titanium and $\mathrm{B}_{4} \mathrm{C}$ powders were homogeneouly dispersed in the aluminum matrix.

2) In the VCS mode, the thin precursor $(1 \mathrm{~mm})$ with a high $\mathrm{Al} / \mathrm{Ti}$ ratio $(\mathrm{Al} / \mathrm{Ti}=7.0)$ did not expand sufficiently. The microstructure of the specimen after the reaction revealed that the reaction between titanium and aluminum was not completed in this specimen.

3) The SHS mode combustion reaction propagated through the whole specimen when the Al/Ti ratio was 4.0 and the thickness of the precursor exceeded $4 \mathrm{~mm}$. However, by reducing the thickness of the precursors to $2 \mathrm{~mm}$ or less, the reaction front did not propagate through the whole specimen. The self-propagation also became difficult by increasing $\mathrm{Al} / \mathrm{Ti}$ ratio to 7.0 .

4) Fine pores with diameters below $1 \mathrm{~mm}$ are dispersed in the specimen by the SHS mode reaction.

\section{References}

Asavavisithchai, S. S., \& Kennedy, A. R. (2006). The effect of compaction method on the expansionand stability of aluminium foams. Advanced Engineering Materials, 8(9), 810-815. http://dx.doi.org/10.1002/adem.200600067 
Banhart, J. (2001). Manufacture, characterization and application of cellular metals and metal foams. Progressin Materials Science, 46(6), 559-632. http://dx.doi.org/10.1016/S0079-6425(00)00002-5

Banhart, J., \& Baumeister, J. (1998). Deformation characteristics of metal foams. Journal of Materials Science, 33(6), 1431-1440. http://dx.doi.org/10.1023/A:1004383222228

Baumeister, J., Banhart, J., \& Weber, M. (1997). Aluminium foams for transport industry. Materials \& Design, 18(4), 217-220. http://dx.doi.org/10.1016/S0261-3069(97)00050-2

Cambronero, L. E. G., Ruiz-Roman, J. M., Corpas, F. A., \& Ruiz Prieto, J. M. (2009). Manufacturing of $\mathrm{Al}-\mathrm{Mg}$-Si alloy foam using calciumcarbonate as foaming agent. Journal of Materials Processing Technology, 209(4), 1803-1809. http://dx.doi.org/10.1016/j.jmatprotec.2008.04.032

Chino, Y., Nakanishi, H., Kobata, M., Iwasaki, H., \& Mabuchi, M. (2002). Processing of a porous 7075 Al alloy by bubble expansion in a semi-solid state. Scripta Materialia, 47(11), 769-773. http://dx.doi.org/10.1016/S1359-6462(02)00299-3

Darolia, R. (2000). Ductility and fracture toughness issues related to implementation of NiAl for gas turbine applications. Intermetallics, 8(9-11), 1321-1327. http://dx.doi.org/10.1016/S0966-9795(00)00081-9

Duarte, I., \& Banhart, J. (2000). A study of aluminium foam formation-kinetics and microstructure. Acta Materialia, 48(9), 2349-2362. http://dx.doi.org/10.1016/S1359-6454(00)00020-3

Dumez, M. C., Marin-Ayral, R. M., \& Tedenac, J. C. (1998). The role of experimental parameters in combustion synthesis of NiAlunder high gas pressure. Journal of Alloysand Compounds, 268(1-2), 141-151. http://dx.doi.org/10.1016/S0925-8388(97)00620-8

Gergely, V., \& Clyne, T. W. (2004). Drainage in standing liquid metal foams: modelling andexperimental observations. Acta Materialia, 52(10), 3047-3058. http://dx.doi.org/10.1016/j.actamat.2004.03.007

Hodge, A. M., \& Dunand, D. C. (2001). Synthesis of nickel-aluminide foams by pack-aluminizationof nickel foams. Intermetallics, 9(7), 581-589. http://dx.doi.org/10.1016/S0966-9795(01)00047-4

Inoguchi, N., Kobashi, M., \& Kanetake, N. (2009). Effect of precursor preparation conditions on combustion synthesis of Al-Ti foams. The Minerals, Metals and Materials Society - 3rd International Conference on Processing Materials for Properties (PMP III), 1, 193-197.

Inoguchi, N., Kobashi, M., \& Kanetake, N. (2009).Synthesis of porous Al3Ti/Alcomposite and effect of precursor processing condition on cell morphology. Materials Transactions, 50(11), 2609-2614. http://dx.doi.org/10.2320/matertrans.L-M2009823

Kandalova, E. G., Nikitin, V. I., Wanqi. J., \& Makarenko, A. G. (2002). Effect of Al powder content on SHS Al-Ti grain refiner. Materials Letters, 54(2), 131-134. http://dx.doi.org/10.1016/S0167-577X(01)00550-X

Kanetake, N., \& Kobashi, M. (2006). Innovative processing of porous and cellular materials by chemical reaction. Scripta Materialia, 54(4), 521-525. http://dx.doi.org/10.1016/j.scriptamat.2005.10.063

Kennedy, A. R. (2002). The effect of $\mathrm{TiH}_{2}$ heat treatment on gas releaseand foaming in $\mathrm{Al}-\mathrm{TiH}_{2}$ preforms. Scripta Materialia, 47(11), 763-767. http://dx.doi.org/10.1016/S1359-6462(02)00281-6

Kennedy, A. R., \& Lopez, V. H. (2003). The decomposition behavior of as-received and oxidized $\mathrm{TiH}_{2}$ foaming-agent powder. Materials Science and Engineering, A357(1-2), 258-263. http://dx.doi.org/10.1016/S0921-5093(03)00211-9

Kobashi, M. N., \& Kanetake, N. (2010). Foaming Technique of Porous Aluminum/Intermetallics Composites by Precursor Method. Proc. 12th inter. Conf. Aluminum Alloys (ICAA12), 1627-1632.

Kobashi, M., Inoguchi, N., \& Kanetake, N. (2010). Effect of elemental powder blending ratio on combustion foaming behavior of porous $\mathrm{Al}-\mathrm{Ti}$ intermetallics and $\mathrm{Al}_{3} \mathrm{Ti} / \mathrm{Al}$ composites. Intermetallics, 18(5), 1039-1045. http://dx.doi.org/10.1016/j.intermet.2010.01.034

Lee, S. H., Lee, J. H., Lee, Y. H., Shin, D. H., \& Kim, Y. S. (2000). Effect of heating rate on the combustion synthesis of intermetallics. Materials Science and Engineering A, 281(1-2). 275-285. http://dx.doi.org/10.1016/S0921-5093(99)00715-7

Matijasevic, B., \& Banhart, J. (2006). Improvement of aluminium foam technology by tailoring of blowing agent. Scripta Materialia, 54(4), 503-508. http://dx.doi.org/10.1016/j.scriptamat.2005.10.045

Matijasevic-Lux, B., Banhart, J., Fiechter, S., Gorke, O., \& Wanderka, N. (2006). Modification of titanium hydride for improved aluminiumfoam manufacture. Acta Materialia, 54(7), 1887-1900. 
http://dx.doi.org/10.1016/j.actamat.2005.12.012

Morsi, A. (2012). The diversity of combustion synthesis processing: a review. J. Mater. Sci., 47, 68-92. http://dx.doi.org/10.1007/s10853-011-5926-5

Varma. A., \& Lebrat. J. P. (1992). Combustion synthesis of advanced materials. Chem. Eng. Sci., 47(9-11), 2179-2194. http://dx.doi.org/10.1016/0009-2509(92)87034-N

Zeppelin, F., Hirscher, M., Stanzick, H., \& Banhart, J. (2003). Desorption of hydrogen from blowing agents used forfoaming metals. Composites Science and Technology, 63(16), 2293-2300. http://dx.doi.org/10.1016/S0266-3538(03)00262-8

Zhao, Y., Taya, M., Kang, Y., \& Kawasaki, A. (2005). Compression behavior of porous NiTi shape memory alloy. Acta Materialia, 53(2), 337-343. http://dx.doi.org/10.1016/j.actamat.2004.09.029 